\title{
ANALISIS KINERJA KEUANGAN PERUSAHAAN SEBELUM DAN SESUDAH SEASONED EQUITY OFFERINGS DI BURSA EFEK JAKARTA
}

\author{
N. Agus Sunarjanto (n_agus_sunarjanto@yahoo.co.id) \\ UNIKA Widya Mandala Surabaya
}

\begin{abstract}
Seasoned Equity Offering (SEO) is an additional public offering of a company's shares in order to generate extra financing for business expansion or fulfillment of its liability. Based on Jakarta Stock Exchange data, 11 listed companies conducted SEO during year 2001. However, only 8 companies meet the requirements as samples for this research. In order to evaluate financial and operational variables, this research uses financial statement figures published 2 year prior and after SEO's. Current ratio (CR), debt to equity ratio (DER) are chosen to represent financial variables, while net profit margin (NPM) and return on investment (ROI) represent operational variables. This research reveals that there was no significant difference in financial performance before and after SEO's. It happened due to several factors, such as: (1) the fund generated from SEO's were used to settle matured debts; and (2) foreign currency denominated debts which increased in value during the period of economic crisis.
\end{abstract}

Keywords: current ratio, debt to equity ratio, seasoned equity offering.

Memasuki era pasar bebas, persaingan dalam dunia usaha menjadi semakin ketat. Kondisi tersebut menuntut perusahaan untuk mengembangkan strategi perusahaan agar dapat bersaing bahkan menjadi semakin berkembang. Krisis moneter yang melanda Indonesia sejak pertengahan tahun 1997, mengakibatkan sejumlah perusahaan membutuhkan dana segar lebih banyak untuk membayar hutangnya yang membengkak akibat depresiasi nilai tukar rupiah terhadap US dolar. Sedangkan untuk meminjam dana dari pinjaman bank menjadi sangat sulit karena bank sendiri mengalami kesulitan likuiditas dalam krisis perbankan nasional. Dan kalaupun ada bank yang mau memberikan pinjaman, maka bank akan membebani dengan bunga yang sangat tinggi sehingga semakin menyulitkan perusahaan.

Dalam perkembangannya, perusahaan yang telah go public ternyata masih membutuhkan sumber dana untuk membiayai kegiatannya. Sumber dana dapat berasal dari luar perusahaan ketika jumlah dana yang dibutuhkan melebihi jumlah yang tersedia dari sumber dana intern perusahaan. Seasoned Equity Offerings (SEO) merupakan penawaran saham tambahan yang dilakukan perusahaan yang listed di pasar modal, di luar saham yang terlebih dahulu beredar di masyarakat melalui initial public offerings (IPO) (Megginson, 1997). Penawaran ini dilakukan karena perusahaan tersebut membutuhkan tambahan dana untuk membiayai kegiatan usaha atau membayar hutangnya yang jatuh tempo. 
Penjualan seasoned securities ini dapat dilakukan dengan 2 cara: pertama, melalui mekanisme right issue atau warrant yaitu menjual hak (right) kepada pemegang saham lama untuk membeli saham baru dengan harga tertentu; kedua, dijual kepada setiap investor yang ingin membeli sekuritas baru melalui second offerings, third offerings, dan seterusnya, yaitu menjual ekuitas tambahan tersebut tidak hanya kepada pemegang saham lama tetapi juga kepada setiap investor di pasar yang ingin membelinya. Namun, perusahaan dengan kepemilikan akan cenderung menggunakan right issue untuk menambah ekuitas barunya (Eckbo dan Masulis, 1992). Karena itu, SEO dapat menjadi solusi terbaik untuk memperoleh dana yang dibutuhkan perusahaan. Selain itu, SEO merupakan sumber dana dengan proses yang lebih mudah dan cepat bila dibandingkan dengan perolehan dana dari sumber lain.

Perusahaan lebih memilih melakukan SEO dibandingkan meminjam dari bank untuk mengembangkan usahanya, karena penawaran saham tambahan ini memerlukan biaya lebih murah dibandingkan meminjam dari bank. SEO tidak memerlukan jaminan (biasanya berupa barang berharga) dan bunga yang harus dibayarkan secara kontinu. Pada saat SEO, perusahaan memerlukan prospektus penawaran yang berisi laporan keuangan untuk menarik minat publik.

Walaupun beberapa penelitian di atas menyimpulkan terjadinya penurunan kinerja pada perusahaan-perusahaan yang melakukan SEO, namun tentunya hasil dan kesimpulan penelitian tersebut tidak dapat digeneralisir untuk pasar modal Indonesia sehingga penelitian ini bermaksud menguji kinerja keuangan perusahaan yang melakukan SEO di pasar modal Indonesia, khususnya untuk perusahaan go public yang terdaftar (listed) di Bursak Efek Jakarta (BEJ) layak untuk dilakukan.

Berdasarkan kondisi dan fakta tersebut, permasalahan dalam penelitian ini adalah "apakah ada perbedaan kinerja keuangan sebelum dan sesudah SEO?" Penelitian bertujuan untuk memperoleh jawaban atas masalah yang ada, yaitu untuk mengetahui adanya perbedaan kinerja perusahaan sebelum dan sesudah SEO.

Rasio keuangan telah lama digunakan sebagai alat untuk menguji manfaat laporan keuangan untuk berbagai peristiwa seperti prediksi kebangkrutan (Thomson, 1991) serta memprediksi keuntungan saham (Machfoedz, 1994; Zainuddin dan Hartono,1999). Penelitian Machfoedz (1994) membahas manfaat rasio keuangan untuk menilai kinerja dan efisiensi perusahaan sebelum dan sesudah krisis moneter. Tingkat efisiensi perusahaan diprediksikan melalui tiga kelompok rasio: likuiditas, leverage, dan keuntungan. Hasilnya menunjukkan bahwa seluruh rasio keuangan berbeda secara signifikan setelah krisis dibandingkan dengan masa sebelum krisis, kecuali untuk debt to equity ratio. Secara khusus, rasio yang berbeda tersebut menunjukkan masa sesudah krisis, efisiensi perusahaan terpengaruh oleh krisis moneter.

Loughran dan Ritter (1997) menggunakan enam rasio keuangan untuk melihat kinerja keuangan lima tahun sebelum dan sesudah melakukan right issue. Hasilnya menunjukkan rasio keuangan mengalami penurunan selama empat tahun sesudah penawaran ekuitas tersebut, terutama untuk ratio profit margin dan Return of Investment (ROI). Hal ini menunjukkan adanya upaya manajemen perusahaan untuk memanipulasi kinerja sebelum melakukan right issue agar kinerja perusahaan pada saat right issue kelihatan bagus.

Penelitian Harto (2001) yang hanya menfokuskan pada penawaran right issue, yaitu salah satu bentuk SEO. yaitu meneliti kinerja keuangan dan operasi perusahaan yang melakukan right issue di Bursa Efek Jakarta. Kinerja selama dua tahun, baik selama maupun sesudah melakukan right issue diamati dengan menggunakan sembilan rasio keuangan serta return saham. Hasilnya menunjukkan untuk jangka waktu satu tahun sebelum right issue dibandingkan dengan satu dan dua 
tahun setelah right issue terdapat enam rasio yang signifikan, yaitu current ratio, ATO, ROI, ROE, PER, dan PBV. Penurunan nilai mean selain current ratio menunjukkan kinerja operasi, keuntungan dan saham perusahaan, mengalami penurunan pasca right issue.

Penelitian Suhardito (2001) menggunakan rasio keuangan untuk memprediksi perubahan laba industri perbankan yang terdaftar di Bursa Efek Surabaya (BES). Rasio-rasio tersebut adalah rasio solvabilitas yang terdiri dari capital ratio, primary ratio, dan rasio keuntungan yang terdiri dari gross profit margin (GPM) dan return on equity (ROE).

Penelitian mengenai SEO di Indonesia masih jarang dilakukan, khususnya penelitian mengenai penurunan kinerja keuangan yang terjadi setelah perusahaan melakukan penawaran saham tambahan tersebut.

\section{Pengertian Kinerja Keuangan Perusahaan}

Posisi perusahaan yang mantap tidak hanya ditunjang dengan modal serta aset yang cukup, namun harus dilengkapi dengan kinerja keuangan perusahaan yang baik pula sehingga mampu menjadi tolak ukur prestasi. Dari laporan-laporan yang disampaikan mampu diperoleh informasi sehubungan dengan posisi keuangan dan hasil-hasil apa yang telah dicapai oleh perusahaan yang bersangkutan. Data keuangan tersebut akan penting artinya baik bagi pihak manajemen maupun bagi pihak luar terutama calon investor untuk mendukung keputusan yang akan diambil.

Sehubungan dengan kinerja keuangan perusahaan, Helfert (1996) mengemukakan kinerja perusahaan adalah hasil dari semua keputusan manajemen yang dilakukan secara terus-menerus. Oleh karena itu, untuk menilai kinerja keuangan kumulatif dan ekonomi diperoleh dari keputusankeputusan itu. Analisis kinerja keuangan ini didasarkan pada data keuangan yang dipublikasikan, seperti tercermin dalam laporan keuangan yang dibuat sesuai dengan prinsip-prinsip akuntansi yang lazim digunakan. Menurut Sartono (1996) analisis keuangan yang mencakup analisis rasio-rasio keuangan sangat membantu dalam menilai prestasi kinerja keuangan di masa lalu dan prospeknya di masa yang akan datang.

Rasio tersebut dapat memberikan indikasi apakah perusahaan memiliki kas yang cukup untuk memenuhi kewajiban finansialnya dan struktur modal yang sehat sehingga tujuan memaksimalkan kemakmuran pemegang saham dapat dicapai. Rasio keuangan yang komprehensif dapat digunakan untuk mengevaluasi kesehatan keuangan perusahaan. Rasio keuangan membantu kita mengidentifikasikan beberapa kekuatan dan kelemahan keuangan perusahaan. Di luar keterbatasannya, rasio keuangan dapat menjadi alat yang sangat berguna untuk menilai kondisi keuangan perusahaan. Para investor mempergunakan rasio keuangan ini sebagai alat untuk mengevaluasi nilai saham, selain itu juga dapat dipergunakan untuk mengukur adanya jaminan atas keamanan dana yang akan ditanamkan pada perusahaan.

Selanjutnya Helfert (1996) mengemukakan bahwa dalam mengevaluasi kinerja perusahaan yang paling berkepentingan adalah pemilik perusahaan dalam hal ini investor, manajer, kreditur, pemerintah dan masyarakat. Para investor berkepentingan terhadap risiko yang melekat dan hasil pengembangan dari investasi yang dilakukannya. Investor ini membutuhkan informasi untuk membantu menentukan apakah harus membeli, menahan atau menjual. Selain itu, mereka juga tertarik pada informasi yang memungkinkan melakukan penilaian terhadap kemampuan perusahaan dalam membayar dividen. Para manajer (termasuk karyawan didalamnya) tertarik pada informasi mengenai stabilitas perusahaan. Mereka juga tertarik pada informasi yang memungkinkan mereka melakukan penilaian atas kemampuan perusahaan dalam memberikan balas jasa, manfaat pensiun 
dan kesempatan kerja. Selain itu, tanggung jawab atas efisiensi dan efektivitas penggunaan dana dan sumber-sumber ekonomi lainnya dalam pengelolaan perusahaan.

Para kreditur (pemberi pinjaman baik yang bersifat jangka pendek maupun jangka panjang) tertarik dengan informasi keuangan yang memungkinkan mereka untuk memutuskan apakah pinjaman pokok serta bunganya dapat dibayar pada saat jatuh tempo, baik tentang jumlah maupun waktu pembayaran. Kemampuan memenuhi kewajiban ini ditandai oleh nilai aktiva yang dimiliki oleh perusahaan sebagai jaminan atas investasinya serta jaminan atas risiko yang dihadapi kreditur tersebut. Pemerintah dan berbagai lembaga yang berada di bawah kekuasaannya yang berkepentingan dalam evaluasi kinerja keuangan suatu perusahaan. Pengalokasian perusahaan dengan sumber dayanya dan aktivitas perusahaan. Dengan demikian, pemerintah dapat mengatur aktivitas perusahaan, menetapkan kebijakan pajak dan sebagai dasar untuk menyusun stastistik pendapatan nasional dan statistik lainnya. Dan pihak terakhir yang berkepentingan adalah masyarakat. Perusahaan mempengaruhi anggota masyarakat dalam berbagai cara seperti pemberian kontribusi pada perekonomian nasional termasuk jumlah orang yang dipekerjakan dan perlindungan kepada penanam modal domestik. Laporan keuangan dapat membantu masyarakat dalam menyediakan informasi kecenderungan (trend) dan perkembangan terakhir kemakmuran perusahaan serta rangkaian aktivitasnya.

Rasio dapat memberikan indikasi antara lain tentang: apakah suatu perusahaan memiliki kas yang cukup untuk memenuhi kewajiban finansialnya, berapa besarnya prosentase laba yang dihasilkan. Analisa rasio merupakan suatu bentuk, cara atau metode yang umum digunakan dalam analisa laporan suatu perusahaan. Sedangkan S. Munawir (1997) mengemukakan bahwa rasio adalah gambaran suatu hubungan atau perimbangan (mathematical judgement) antara suatu jumlah tertentu dengan jumlah yang lain.

Penggunaan analisa rasio dimungkinkan untuk menentukan tingkat likuiditas, solvabilitas dan derajat keuntungan (profitabilitas/rentabilitas) suatu perusahaan. Ada bermacam-macam penggolongan rasio keuangan, menurut Weston dan Brigham (1981) dibagi atas enam macam rasio, yaitu rasio likuiditas, rasio leverage, rasio aktivitas, rasio profitabilitas, rasio pertumbuhan dan rasio penilaian. Sedangkan Riyanto (1995) membagi empat kelompok, yaitu:

1. Rasio Likuiditas; mengukur kemampuan perusahaan untuk memenuhi kewajiban jangka pendek tepat pada waktunya. Dua rasio yang mampu dipergunakan adalah current ratio dan quick ratio. Current ratio adalah rasio yang dipergunakan untuk mengukur kemampuan perusahaan untuk melunasi kewajiban lancar dengan menggunakan aktiva lancar. Quick ratio adalah rasio yang dipergunakan untuk mengukur kemampuan perusahaan untuk melunasi kewajiban lancar dengan menggunakan aktiva yang paling likuid (quick asset), yaitu kas, surat berharga dan piutang.

2. Rasio Leverage; mengukur seberapa besar perusahaan dibiayai dengan hutang, baik jangka pendek maupun jangka panjang. Rasio ini terdiri dari debt to total asset ratio dan debt to equity ratio. Debt to total asset adalah rasio yang menjelaskan seberapa besar harta perusahaan yang didanai oleh hutang. Sedangkan debt to equity ratio dipakai untuk mengukur proporsi hutang terhadap modal sendiri.

3. Rasio Aktivitas; mengukur sejauh mana efektivitas perusahaan dalam menggunakan sumber dayanya, Beberapa rasio aktivitas antara lain inventory turnover ratio dan total assets turnover ratio. Inventory turnover adalah rasio yang mengukur perputaran dana yang tertanam pada persediaan. Total assets turnover adalah rasio yang menunjukkan tingkat efisiensi penggunaan keseluruhan aktiva perusahaan di dalam menghasilkan volume penjualan tertentu. 
4. Rasio Keuntungan; mengukur efektivitas manajemen perusahaan secara keseluruhan. Atau dengan kata lain seberapa besar kemampuan perusahaan dalam memperoleh laba. Beberapa rasio profitabilitas ini antara lain return on assets yaitu rasio untuk mengukur laba bersih yang diperoleh dari harta perusahaan, serta return on equity yaitu rasio untuk mengukur laba bersih yang diperoleh dari modal yang diinvestasikan oleh pemilik perusahaan.

\section{Seasoned Equity Offerings}

Seasoned Equity Offerings (SEO) merupakan penawaran sekuritas tambahan (seasoned securities) kepada masyarakat yang dilakukan oleh perusahaan yang telah go public (Megginson, 1997). Penawaran ini dilakukan karena perusahaan yang telah go public tersebut membutuhkan tambahan dana untuk membiayai kegiatan usahanya (Harto, 2001). Penjualan seasoned securities ini dapat dilakukan dengan berbagai cara, yaitu (Megginson, 1997):

1. Menjual hak (right) kepada pemegang saham lama untuk membeli saham baru dengan harga tertentu (disebut dengan right issues).

2. Menjual kepada setiap investor yang ingin membeli sekuritas baru tersebut melalui second offerings, third offerings dan seterusnya.

Perusahaan dengan kepemilikan yang terkonsentrasi akan cenderung menggunakan right issue untuk memperoleh ekuitas baru. Emery dan Finnerty (1997) mengemukakan bahwa right issue merupakan penawaran sekuritas baru yang memberi prioritas kepada pemegang saham perusahaan (stockholders) untuk membeli sekuritas baru tersebut pada harga tertentu pada saat tertentu pula. Jadi, perusahaan mendistribusikan rights (opsi) kepada pemegang saham agar dapat memperoleh sekuritas-sekuritas baru dengan harga khusus. Alasan mengapa perusahaan menawarkan sekuritas tambahannya melalui right issue adalah untuk melindungi kepentingan pemegang saham perusahaan, khususnya dalam melaksanakan hak preemptive (preemptive right) (Hartono, 2002).

Hak preemptive dilaksanakan agar pemegang saham lama tetap dapat mempertahankan proporsi kepemilikan saham perusahaan sama dengan seperti sebelum dilakukannya SEO (Hartono, 2000). Dalam hak ini biasanya pemilik satu lembar saham lama akan diberi hak untuk membeli satu lembar saham baru. Kemudian pemegang saham lama akan menerima bukti right sesuai dengan jumlah saham yang dimilikinya (Husnan, 1996). Apabila pemegang saham lama tidak menggunakan haknya maka hak ini dapat ditawarkan ke pasar.

Seasoned offerings atau third offerings merupakan penawaran sekuritas tambahan langsung kepada masyarakat, tanpa memberi hak istimewa kepada pemegang saham lama (stockholders) (Megginson, 1997). Berbeda dengan proses IPO, dalam SEO investor memiliki pegangan dalam menentukan harga surat berharga tambahan tersebut yaitu harga pasar saham sekuritas perusahaan bersangkutan yang telah beredar di masyarakat, sekuritas tambahan tersebut akan dinilai paling tidak sebesar harga pasar sekuritas yang telah beredar tersebut.

Berdasarkan penelitian terdahulu dan kajian teori, maka hipotesis dalam penelitian ini adalah ada perbedaan kinerja keuangan perusahaan sebelum dan sesudah Seasoned Equity Offerings (SEO).

Penelitian ini menggunakan dua variabel yaitu variabel keuangan dan variabel operasi. Variabel keuangan akan diukur dengan current ratio dan leverage ratio. Sedangkan variabel operasi akan diukur dengan menggunakan net profit margin dan return on investment ratio (Loughran dan Ritter, 1997; Harto, 2001). Variabel-variabel yang digunakan dalam penelitian ini didefinisikan secara operasional sebagai berikut. 
Kinerja Keuangan adalah kondisi kesehatan perusahaan yang diukur melalui ratio-ratio keuangan sebagai berikut.

1. Current Ratio

Current Ratio merupakan rasio yang menghubungkan aktiva lancar dengan hutang lancar. Aktiva lancar terdiri dari kas, surat-surat berharga, piutang usaha dan persediaan. Hutang lancar terdiri dari hutang usaha, pinjaman bank dan biaya-biaya lain yang masih harus dibayar.

$$
\text { Current Ratio }(\mathrm{CR})=\frac{\text { Aktiva Lancar }}{\text { Hutang Lancar }}
$$

2. Leverage Ratio

Leverage Ratio menunjukkan besarnya modal yang berasal dari pinjaman yang dipergunakan untuk membelanjai investasinya. Oleh karena itu, makin banyak menggunakan modal asing maka semakin besar ratio leverage-nya dan berarti makin besar pula risiko yang dihadapi perusahaan. Penelitian ini hanya akan menggunakan Debt Equity Ratio, yaitu perbandingan antara total hutang (hutang jangka panjang dan hutang lancar) dengan modal sendiri (modal saham biasa dan laba ditahan).

$$
\text { Debt Equity Ratio }(\mathrm{DER})=\frac{\text { Total Hutang }}{\text { Total Modal Sendiri }}
$$

3. Net Profit Margin Ratio

Net Profit Margin Ratio merupakan prosentase dari sisa penjualan setelah sebuah perusahaan membayar barangnya.

$$
\text { Net Profit Margin (NPM) }=\frac{\text { Laba Bersih }}{\text { Penjualan }}
$$

4. Return on Investment Ratio

Return on Investment Ratio merupakan rasio untuk mengukur kekuatan penghasilan terhadap aktiva. Rasio tersebut menyatakan kemampuan perusahaan dalam memperoleh penghasilan terhadap operasi bisnis dan menjadi ukuran keefektifan manajemen. Hal ini sama dengan laba bersih dibagi oleh jumlah aktiva rata-rata.

$$
\text { Return On Investment Ratio }(\mathrm{ROI})=\frac{\text { Laba Bersih }}{\text { Total Aktiva }}
$$

Seasoned Equity Offering adalah penawaran sekuritas tambahan kepada masyarakat yang dilakukan oleh perusahaan yang go public.

Jenis data yang dipergunakan dalam melakukan penelitian ini adalah:

1. Data kualitatif, yaitu data yang tidak berupa angka yang meliputi teori-teori tentang kinerja keuangan, rasio keuangan dan penawaran saham tambahan (SEO).

2. Data kuantitatif, yaitu data yang berasal dari laporan keuangan perusahaan. 
Sumber data yang digunakan dalam penelitian ini adalah data sekunder yang berupa laporan keuangan dari masing-masing perusahaan go public yang melakukan SEO selama tahun 2001. Semua data ini diperoleh dari perpustakaan Bursa Efek Jakarta.

Metode pengumpulan data yang digunakan dalam penelitian adalah dokumentasi laporan keuangan tahunan perusahaan yang go public di BEJ yang kemudian dilakukan rekapitulasi sesuai dengan kebutuhan.

Populasi data mencakup 11 perusahaan dan sampel yang diambil adalah 8 perusahaan yang tergabung dalam perusahaan go-public yang listed di BEJ yang melakukan SEO selama tahun 2001 (Lampiran). Sampel diambil secara non random yaitu purposive sampling di mana setiap perusahaan yang masuk dalam pemilihan sampel penelitian disyaratkan mempunyai laporan keuangan yang dipublikasikan selama 2 (dua) tahun sebelum dan 2 (dua) tahun sesudah SEO yaitu perusahaan yang melakukan penawaran saham tambahan dan merupakan perusahaan lembaga non-keuangan untuk mengantisipasi kemungkinan pengaruh regulasi tertentu yang bersifat khas yang dapat mempengaruhi variabel penelitian.

Teknik analisis data yang digunakan untuk menjawab hipotesis dalam penelitian ini adalah dengan menggunakan analisa kuantitatif, yaitu metode analisis data dengan menggunakan teknikteknik perhitungan statistik. Alat analisis kuantitatif yang digunakan dalam penelitian ini adalah uji beda (uji T), yaitu analisis untuk menguji mean populasi yang didasarkan pada pengamatan random sampel yang jumlahnya relatif kurang dari 30. Pengujian hipotesis dilakukan dengan langkah-langkah sebagai berikut.

1. Merumuskan hipotesis statistik, yaitu: $\mathrm{H}_{0}: \mu_{1}=\mu_{2}$ : tidak ada perbedaan

$$
\mathrm{H}_{1}: \mu_{1}<\mu_{2} \text { : ada perbedaan }
$$

2. Perhitungan statistik dilakukan dengan menggunakan uji beda (paired sample t-test) :

$$
\sqrt{\overline{\mathrm{d}}=\frac{\Sigma \mathrm{d}}{\mathrm{n}}} ; \mathrm{s} \overline{\mathrm{d}}=\frac{\mathrm{sd}}{\sqrt{\mathrm{n}}} ; \mathrm{sd}=\sqrt{\frac{\Sigma(\mathrm{d}-\overline{\mathrm{d}})^{2}}{\mathrm{n}-1}} ; \mathrm{t}=\frac{\overline{\mathrm{d}}-\mu_{0}}{\mathrm{~s} \overline{\mathrm{d}}}
$$

3. Menentukan nilai tabel sesuai dengan pengujian dan a-nya (Nilai Kritis Tabel) yaitu:

Uji secara individu (Uji T) yaitu suatu uji yang membandingkan antara sebelum dan sesudah

secara per komponen, di mana:

Berdasar perbandingan t hitung dengan $t$ tabel:

Terima $\mathrm{H}_{0}$, tolak $\mathrm{H}_{1}$ jika t hitung $<0.05$

Terima $\mathrm{H}_{1}$, tolak $\mathrm{H}_{0}$ jika t hitung $>0.05$

4. Menggunakan regresi logistik yaitu memprediksi apakah terdapat perbedaan kinerja keuangan perusahaan sebelum dan sesudah penawaran saham tambahan dengan menggunakan dasar rasio keuangan perusahaan, yang di-runs secara bersama-sama dimana:

Berdasar nilai probabilitas:

Terima $\mathrm{H}_{0}$, tolak $\mathrm{H}_{1}$ jika probabilitas $>0.05$

Terima $\mathrm{H}_{1}$, tolak $\mathrm{H}_{0}$ jika probabilitas $<0.05$

5. Mengambil keputusan dan interpretasi atas hasil analisis.

\section{HASIL DAN PEMBAHASAN}

Hasil perhitungan rasio keuangan yang meliputi variabel keuangan dan variabel operasi sebelum SEO dapat dilihat pada Tabel 1. Sedangkan perhitungan rasio keuangan yang meliputi variable keuangan dan operasi sesudah SEO dapat dilihat pada Tabel 2. 
Tabel 1. Hasil Perhitungan Rasio Keuangan Sebelum SEO

\begin{tabular}{cccccc}
\hline Kode & Tahun & CR & DER & NPM & ROI \\
\hline BLTA & 1999 & 0.3941 & 1.4075 & 0.2588 & 0.0592 \\
& 2000 & 0.7401 & 0.0869 & 0.0401 & 0.0271 \\
BHIT & 1999 & 1.8520 & 0.8409 & 0.8608 & 0.2040 \\
& 2000 & 0.1855 & 1.0857 & 0.5888 & 0.1157 \\
HERO & 1999 & 0.8990 & 0.1899 & 0.0091 & 0.0264 \\
& 2000 & 0.1149 & 0.7242 & 0.0399 & 0.0082 \\
INTP & 1999 & 0.2266 & 6.7168 & 0.2963 & 0.0529 \\
& 2000 & 3.4314 & 10.4081 & -0.3586 & -0.0754 \\
LPPF & 1999 & 0.6350 & -2.2973 & -3.1036 & -0.1235 \\
& 2000 & 0.3086 & -1.4975 & 6.0531 & 0.5212 \\
TMPI & 1999 & 0.8300 & 1.0337 & 0.0287 & 0.0085 \\
& 2000 & 0.2523 & 0.8517 & -0.2285 & -0.0921 \\
TIRA & 1999 & 0.9013 & 0.4689 & 0.0480 & 0.0367 \\
& 2000 & 1.8574 & 0.8890 & -0.1625 & -0.1325 \\
ZBRA & 1999 & 0.1967 & 0.0145 & -0.2979 & 0.1527 \\
& 2000 & 0.2522 & 1.0950 & 0.1654 & 0.0921 \\
\hline
\end{tabular}

Sumber: Hasil olahan peneliti

Tabel 2. Hasil Perhitungan Rasio Keuangan Sesudah SEO

\begin{tabular}{cccccc}
\hline Kode & Tahun & CR & DER & NPM & ROI \\
\hline BLTA & 2002 & 1.3325 & 2.1670 & 0.2129 & 0.0556 \\
& 2003 & 1.6366 & 2.6919 & 0.1752 & 0.4137 \\
BHIT & 2002 & 1.4706 & 0.5974 & 0.7106 & 0.0373 \\
& 2003 & 1.1251 & 0.6072 & 0.7948 & 0.0630 \\
HERO & 2002 & 0.1100 & 0.0000 & 0.0127 & 0.0127 \\
& 2003 & 0.8680 & 0.1342 & -0.0074 & -0.0195 \\
INTP & 2002 & 2.9045 & 2.0032 & 0.2637 & 0.0910 \\
& 2003 & 1.8690 & 1.2378 & 0.1612 & 0.0661 \\
LPPF & 2002 & 0.7928 & 7.6179 & 5.2657 & 0.9248 \\
& 2003 & 0.1852 & 15.5763 & 0.3469 & 0.1005 \\
TMPI & 2002 & 0.5700 & 0.4691 & -0.0636 & 0.0113 \\
& 2003 & 0.6400 & 0.5169 & 0.0196 & 0.0066 \\
TIRA & 2002 & 1.1748 & 3.2949 & 0.0367 & 0.0178 \\
& 2003 & 0.6222 & 2.1396 & 0.0120 & 0.0095 \\
ZBRA & 2002 & 0.2996 & 0.8975 & 0.0254 & 0.0147 \\
& 2003 & 0.2568 & 1.2689 & 0.0295 & 0.0123 \\
\hline
\end{tabular}

Sumber: Hasil olahan peneliti

Berdasarkan tabel diatas, pada umumnya rasio-rasio perusahaan sesudah SEO memiliki nilai yang lebih tinggi dari perusahaan sebelum SEO. Hal ini dapat dilihat dari current ratio perusahaan sesudah SEO lebih tinggi daripada sebelum SEO. Hal ini disebabkan karena kemampuan perusahaan untuk membayar hutang jangka pendek lebih baik. Dapat ditunjukkan dari aktiva lancar yang lebih tinggi daripada hutang lancar sehingga current ratio perusahaan sesudah SEO jauh lebih tinggi dari perusahaan sebelum SEO. Selain itu, debt equity ratio perusahaan sesudah SEO juga lebih tinggi dari sebelum SEO. Hal ini disebabkan karena krisis ekonomi yang 
melanda di Indonesia membuat hutang perusahaan dalam mata uang asing (khususnya dollar Amerika) yang tidak dilindungi dengan mekanisme hedging menjadi berlipat ganda sehingga rasio leverage-nya semakin besar. Net profit margin ratio dan return on investment ratio memiliki nilai yang relatif sama baik pada perusahaan sebelum maupun sesudah SEO.

Berikut ini nilai statistik dari masing-masing variabel dari kedua kinerja seperti yang disajikan dalam tabel berikut ini.

Tabel 3 menyajikan nilai statistik dari variabel-variabel penelitian. Dua variabel keuangan, yaitu CR dan DER, mempunyai nilai sebelum SEO lebih kecil dibandingkan dengan nilai sesudah peristiwa tersebut. Sedangkan variabel operasi yang lain, yaitu NPM dan ROI juga memiliki nilai sebelum SEO lebih kecil dibandingkan dengan nilai sesudah SEO. Hal ini dapat dilihat Tabel 3 dimana mean CR sebelum SEO adalah sebesar 0.8174 dan mean CR setelah melakukan SEO sebesar 0.9911. Hal yang sama juga terjadi pada mean DER sebelum SEO adalah sebesar 1.3762 dan mean DER setelah SEO adalah sebesar 2.5763. Mean NPM sebelum melakukan SEO memiliki nilai yang lebih kecil yaitu sebesar 0.2649 dibandingkan mean NPM sesudah SEO yaitu sebesar 0.4998 . Diikuti dengan, mean ROI sebelum SEO yang memiliki nilai lebih kecil yaitu sebesar 0.0551 bila dibandingkan dengan sesudah SEO yaitu sebesar 0.1136 .

Tabel 3. Nilai statistic dari variable-variabel penelitian

\begin{tabular}{llcccc}
\hline & & Mean & $\mathrm{N}$ & Std. Deviation & Std. Error Mean \\
\hline Pair 1 & CR_SBLM & .8174 & 8 & .54589 & .19300 \\
& CR_SSDH & .9911 & 8 & .70262 & .24841 \\
Pair 2 & DER_SBLM & 1.3762 & 8 & 3.05003 & 1.07835 \\
& DER_SSDH & 2.5763 & 8 & 3.76245 & 1.33023 \\
Pair 3 & NPM_SBLM & .2649 & 8 & .55815 & .19734 \\
& NPM_SSDH & .4998 & 8 & .96572 & .34143 \\
Pair 4 & ROI_SBLM & .0551 & 8 & .09424 & .03332 \\
& ROI_SSDH & .1136 & 8 & .17881 & .06322 \\
\hline
\end{tabular}

Sumber: Hasil Olahan Peneliti

Untuk memastikan apakah perbedaan tersebut secara signifikan berpengaruh terhadap hipotesis yang diajukan dalam penelitian akan dilakukan uji beda terhadap nilai-nilai tersebut.

Hasil perhitungan statistik kinerja keuangan perusahaan sebelum dan sesudah melakukan SEO dengan menggunakan uji beda (paired sample t-test) ditunjukkan di Tabel 4.

Tabel 4. Uji Dua Rata-Rata terhadap SEO Paired Samples Test

\begin{tabular}{|c|c|c|c|c|c|c|c|c|c|}
\hline \multicolumn{10}{|c|}{ Paired Differences } \\
\hline & & \multirow[b]{3}{*}{ Mean } & \multirow[b]{3}{*}{ Std.Dev } & \multirow{3}{*}{$\frac{\text { Std. Error }}{\text { Mean }}$} & \multirow{2}{*}{\multicolumn{2}{|c|}{$\begin{array}{l}\text { 95\% Confidence } \\
\text { Interval of Difference }\end{array}$}} & \multirow[b]{3}{*}{$t$} & \multirow[b]{3}{*}{$d f$} & \multirow[b]{3}{*}{ Sig2tailed } \\
\hline & & & & & & & & & \\
\hline & & & & & Lower & Upper & & & \\
\hline Pair 1 & cr sblm-cr ssdh & -0.1738 & 0.4189 & 0.1481 & -0.5239 & 0.1764 & -1.1734 & 7 & 0.2790 \\
\hline Pair 2 & der sblm-der ssdh & -1.2001 & 5.6886 & 2.0112 & -5.9559 & 3.5557 & -0.5967 & 7 & 0.5695 \\
\hline Pair 3 & npm sblm-npm ssdh & -0.2349 & 0.4497 & 0.1590 & -0.6109 & 0.1410 & -1.4775 & 7 & 0.1831 \\
\hline Pair 4 & roi sblm-roi ssdh & -0.0585 & 0.1447 & 0.0511 & -0.1795 & 0.0624 & -1.1444 & 7 & 0.2901 \\
\hline
\end{tabular}

Sumber: Hasil olahan peneliti 
Dari Tabel 4 di atas terlihat bahwa perbedaan rata-rata CR sebelum dan sesudah Seasoned Equity Offerings adalah sebesar -0.1738 dengan standar deviasi sebesar 0.4189 . Hasil perhitungan $t$ statistik menghasilkan nilai sebesar -1.1734 dan signifikansi 0.2790 . Nilai negatif pada t statistik tersebut menunjukkan bahwa mean $\mathrm{CR}$ sebelum penawaran saham tambahan lebih kecil dibandingkan mean $\mathrm{CR}$ sesudah penawaran saham tambahan. Nilai signifikansi sebesar 0.2790 menunjukkan bahwa $\mathrm{H}_{0}$ diterima dan $\mathrm{H}_{1}$ ditolak, yaitu tidak ada perbedaan kinerja keuangan perusahaan sebelum dan sesudah dilakukan penawaran saham tambahan. Sedangkan, perbedaan rata-rata DER sebelum dan sesudah Seasoned Equity Offerings adalah sebesar -1.2001 dengan standar deviasi sebesar 5.6886. Hasil perhitungan t statistik menghasilkan nilai sebesar -0.5967 dan signifikansi 0.5695 . Nilai negatif pada t statistik tersebut menunjukkan bahwa mean DER sebelum penawaran saham tambahan lebih kecil dibandingkan mean DER sesudah penawaran saham tambahan. Nilai signifikansi sebesar 0.5695 menunjukkan bahwa $\mathrm{H}_{0}$ diterima dan $\mathrm{H}_{1}$ ditolak, yaitu tidak ada perbedaan kinerja keuangan perusahaan sebelum dan sesudah dilakukan penawaran saham tambahan.

Perbedaan rata-rata NPM sebelum dan sesudah Seasoned Equity Offerings adalah sebesar -0.2349 dengan standar deviasi sebesar 0.4497 . Hasil perhitungan $t$ statistik menghasilkan nilai sebesar -1.4775 dan signifikansi 0.1831 . Nilai negatif pada t statistik tersebut menunjukkan bahwa mean NPM sebelum penawaran saham tambahan lebih kecil dibandingkan mean NPM sesudah penawaran saham tambahan. Nilai signifikansi sebesar 0.1831 menunjukkan bahwa $\mathrm{H}_{0}$ diterima dan $\mathrm{H}_{1}$ ditolak, yaitu tidak ada perbedaan kinerja keuangan perusahaan sebelum dan sesudah dilakukan penawaran saham tambahan.

Demikian halnya pada perbedaan rata-rata ROI sebelum dan sesudah Seasoned Equity Offerings adalah sebesar -0.0585 dengan standar deviasi sebesar 0.1447 . Hasil perhitungan $t$ statistik menghasilkan nilai sebesar -1.1444 dan signifikansi 0.2901 . Nilai negatif pada t statistik tersebut menunjukkan bahwa mean ROI sebelum penawaran saham tambahan lebih kecil dibandingkan mean ROI sesudah penawaran saham tambahan. Nilai signifikansi sebesar 0.2901 menunjukkan bahwa $\mathrm{H}_{0}$ diterima dan $\mathrm{H}_{1}$ ditolak, yaitu tidak ada perbedaan kinerja keuangan perusahaan sebelum dan sesudah dilakukan penawaran saham tambahan.

Hasil uji regresi logistik (Tabel 5) nilai Cox Snell's $R$ Square sebesar 0,078 dan nilai Nagelkerke $\mathrm{R}^{2}$ adalah 0.104 yang berarti variabilitas variabel dependen yang dapat dijelaskan oleh variabilitas variabel independen sebesar 10,4\%. Dalam hal ini, variabel dependen diwakili oleh kinerja keuangan dan variabel independen diwakili oleh rasio keuangan. Untuk menilai kelayakan model regresi dalam memprediksi digunakan uji Chi Square Hosmer dan Lemshow Test untuk menguji hipotesis. Dari hasil pengujian pada tabel 4.6. diperoleh nilai Chi Square sebesar 3.422 dengan nilai signifikansi sebesar 0.754. Pada hasil tersebut terlihat bahwa nilai signifikansi lebih besar daripada alpha (0.05), yang berarti keputusan yang diambil adalah menerima Ho yaitu tidak ada perbedaan antara klasifikasi yang diprediksi dengan klasifikasi yang diamati. Pada tabel klasifikasi terlihat nilai prediksi kinerja keuangan sebelum adalah 6 dan sesudah adalah 3, dengan ketepatan kinerja keuangan sebelum SEO 75\% dan kinerja keuangan sesudah SEO adalah 37.5\%. Secara keseluruhan hasil klasifikasi menunjukkan persentase ketepatan klasifikasi adalah sebesar $56.3 \%$. 
Tabel 5. Regression Model Summary

\begin{tabular}{cccc}
\hline Step & -2 Log likelihood & Cox \& Snell $R$ Square & Nagelkerke $R$ Square \\
\hline 1 & $20,878(a)$ & 0,078 & 0,104 \\
\hline
\end{tabular}

a Estimation terminated at iteration number 4 because parameter estimates changed by less than 0,001 .

Hosmer and Lemeshow Test

\begin{tabular}{cccc}
\hline Step & Chi-square & Df & Sig. \\
\hline 3,422 & 6 & 0,754 \\
\hline
\end{tabular}

Classification Table (a)

\begin{tabular}{|c|c|c|c|c|c|}
\hline & & & & & Predicted \\
\hline & & & & uangan & \\
\hline & & & Sebelum & Sesudah & Percentage Correct \\
\hline Step 1 & Kinerja Keuangan & Sebelum & 6 & 2 & 75,0 \\
\hline & & Sesudah & 5 & 3 & 37,5 \\
\hline & Overall Percentage & & & & 56,3 \\
\hline
\end{tabular}

a The cut value is 0,500

Variables in the Equation

\begin{tabular}{|c|c|c|c|c|c|c|c|}
\hline & & B & S.E. & Wald & Df & Sig. & $\operatorname{Exp}(B)$ \\
\hline \multirow[t]{5}{*}{ Step 1(a) } & CR &, 527 & ,958 & ,302 & 1 &, 582 & 1,693 \\
\hline & DER & ,035 & 204 & ,029 & 1 & ,866 & 1,035 \\
\hline & NPM & -,303 & 1,514 & ,040 & 1 & ,841 & ,739 \\
\hline & ROI & 4,753 & 8,501 & ,313 & 1 &, 576 & 115,928 \\
\hline & Constant &,- 812 & 1,037 & ,613 & 1 &, 434 & ,444, \\
\hline
\end{tabular}

a Variable(s) entered on step 1: CR, DER, NPM, ROI.

Tidak terdapatnya perbedaan yang signifikan antara kinerja keuangan perusahaan sebelum dan sesudah penawaran saham tambahan (SEO) disebabkan karena beberapa hal: Pertama, dana yang diperoleh dari penawaran digunakan untuk membayar hutang lancar dan untuk membiayai kegiatan usahanya. Sehingga, menurunnya hutang lancar tersebut secara langsung berpengaruh kepada bertambah besarnya nilai current ratio setelah penawaran karena variabel ini diperoleh dari perbandingan aktiva lancar dan hutang lancar. Kedua, krisis ekonomi yang melanda Indonesia membuat hutang perusahaan dalam mata uang asing (khususnya dollar Amerika) yang tidak dilindungi dengan mekanisme hedging menjadi berlipat ganda. Berlipatnya hutang ini secara langsung berdampak terhadap debt equity ratio karena variabel ini diperoleh dari perbandingan total hutang dan total modal sendiri.

Berdasarkan hasil analisis di atas dapat ditarik kesimpulan bahwa tidak terdapat perbedaan kinerja keuangan perusahaan yang signifikan pada sebelum dan sesudah SEO. Dengan demikian, hipotesis pernyataan yang menyatakan ada perbedaaan kinerja keuangan perusahaan sebelum dan sesudah event penawaran saham tambahan (SEO) tidak dapat diterima. 


\section{PENUTUP}

Hasil penelitian menunjukkan bahwa:

1. Tidak ada perbedaan yang signifikan antara kinerja keuangan perusahaan sebelum dan sesudah penawaran saham tambahan (SEO). Hal ini diketahui dari hasil uji beda (paired sample t-test) yang menunjukkan bahwa thitung CR, DER, NPM dan ROI yang lebih kecil dari t tabel.

2. Hasil uji logistik regresi menunjukkan bahwa hasil signifikan sebesar 0,754 lebih besar dari daerah $\alpha 0,05$ yang berarti hipotesis pernyataan ditolak.

Implikasi dari penelitian ini khususnya ditujukan kepada investor dan analis pasar modal dan dunia akademis. Bagi investor dan analis pasar modal untuk lebih berhati-hati dalam menganalisis dan menilai perusahaan yang melakukan penawaran saham tambahan (SEO). Berdasarkan hasil penelitian, disusun saran sebagai berikut:

1. Bagi dunia akademis yang berniat melakukan penelitian sejenis diharapkan dapat mengembangkan penelitian ini dengan menghubungkan kinerja operasi dengan kinerja saham dan bagi penelitian lebih lanjut diharapkan memperbaiki keterbatasan-keterbatasan yang ada dalam penelitian ini dan disarankan menggunakan sampel yang lebih luas.

2. Bagi investor dan analisis modal diharapkan mencari informasi tambahan diluar informasi yang tercantum dalam prospektus penawaran untuk mengetahui nilai dan kondisi perusahaan yang sesungguhnya.

\section{REFERENSI}

Altman. (1968). Financial analysis and prediction of corporate bankruptcy. Journal of Finance, 23 (4), 584-609.

Bursa Efek Jakarta. (2007). Statistik perusahaan go-public yang melakukan SEO tahun 2001. Diambil dari $h$ ttp://www.jsx.co.id/jsx.statistic. Jakarta Stock Exchange.

Eckbo, B.E. \& Masulis. (1992). Adverse selection and the rights offer paradox. Journal of Financial Economics, 32, 293-332.

Emery, F. (1997). Principle of financial management. Prentice Hall.

Harto, $P$, (2001). Analisis kinerja perusahaan yang melakukan right issue di Indonesia. Simposium Nasional Akuntansi IV.

Hartono, J. (2000). Teori portofolio dan analisis investasi. Edisi 2. Yogyakarta: BPFE.

Helfert, E.A. (1991). Analisis laporan keuangan. Edisi Ketujuh. Jakarta: Erlangga.

Husnan Suad. (1996). Dasar-dasar teori portfolio dan analisis sekuritas. Yogyakarta: UPP AMP YKPN.

Loughran, T. \& Jay Ritter. (1997). The operating performance of firms conducting seasoned equity offerings. The Journal of Finance, 52 (2), 1823-1850.

Megginson. (1997). Corporate finance theory. Addison-Wesley Educational Publishers Inc.

Machfoeds, M. (1994). The usefulness of financial ratio in Indonesia. Jurnal Kelola. September 94110.

Munawir, S. (2002). Analisis laporan keuangan. Edisi Keempat. Yogyakarta: Liberty.

Pengolahan Data Statistik dengan SPSS 11.5. Edisi Pertama. Jakarta: Salemba Infotek.

Riyanto Bambang. (1995). Dasar-dasar pembelanjan perusahaan. Edisi IV. Yogyakarta: BPFE Sartono. (1996). Manajemen keuangan: Teori dan aplikasi. Edisi ketiga. Yogyakarta: BPFE.

Suhardito. (2001). Analisa ratio-ratio keuangan dalam memprediksi perubahan laba emiten dari industri perbankan. SNA sesi ke 2. 
Sulistyanto. (2002). Seasoned Equity Offering: Benarkah underperformance pasca penawaran. Pendidikan Network.

Teoh, Siew Hong, Ivo Welch, \& Wong, T.J. (1998). Earning management dan the underperformance of Seasoned Equity Offerings. Journal of Financial Economics, 53 (6), 1935-1974.

Thomson. (1991). Prediction bank failure in 1980's economic review (second quarter). Weston \& Brigham. (1992). Esensials of managerial finance, tenth edition. USA: Dryden Press Zainuddin \& Hartono, Y. (1999). Manfaat ratio keuangan dalam memprediksi pertumbuhan laba: Suatu studi empiris pada perusahaan perbankan di Bursa Efek Jakarta. Jurnal Riset Akuntansi, 2 (1), 66-90. 


\section{LAMPIRAN}

\section{Gambaran Umum Perusahaan Go-public yang Melakukan SEO tahun 2001}

\begin{tabular}{|c|c|c|}
\hline Nama & Kode & Ruang Lingkup \\
\hline PT. Berlian Laju Tanker Tbk & BLTA & $\begin{array}{l}\text { meliputi usaha dalam bidang perkapalan dalam dan luar negeri } \\
\text { dengan menggunakan kapal-kapal, termasuk kapal tanker } \\
\text { tongkang dan kapal tunda (tugboat) }\end{array}$ \\
\hline PT. Bhakti Investama Tbk & BHIT & $\begin{array}{l}\text { Berusaha di bidang perindustrian, pertambangan, kehutanan, } \\
\text { pengangkutan, pertanian, perkebunan, peternakan, perikanan } \\
\text { darat/laut, real estate, arsitektur, pembangunan (pemborongan), } \\
\text { jasa dan perdagangan. }\end{array}$ \\
\hline PT. Hero Supermarket Tbk & HERO & $\begin{array}{l}\text { kegiatan meliputi penjualan retail yaitu bahan-bahan kebutuhan } \\
\text { hidup masyarakat dengan segala perlengkapannya }\end{array}$ \\
\hline PT. Indocement Tunggal Prakasa Tbk & INTP & $\begin{array}{l}\text { kegiatan perusahaan antara lain meliputi pabrik semen dan } \\
\text { bahan-bahan bangunan, makanan, tekstil, konstruksi dan } \\
\text { perdagangan. }\end{array}$ \\
\hline PT. Pasific Utama Tbk & LPPF & $\begin{array}{l}\text { meliputi pemberian jasa, perdagangan umum, konstruksi, jasa } \\
\text { teknik, transportasi, agrobisnis, percetakan dan pertambangan. }\end{array}$ \\
\hline PT. Siloam Health Centre Tbk & TMPI & $\begin{array}{l}\text { kegiatan utama bergerak dalam bidang pelayanan kesehatan } \\
\text { dengan mendirikan dan mengelola rumah sakit umum dan } \\
\text { poliklinik, rumah sakit bersalin dan usaha-usaha lainnya yang } \\
\text { berkaitan dengan kesehatan masyarakat. }\end{array}$ \\
\hline PT. Tira Austenite Tbk & TIRA & $\begin{array}{l}\text { kegiatan perusahaan meliputi usaha dalam bidang ekspor dan } \\
\text { impor, perdagangan dan distributor barang-barang teknik serta } \\
\text { kontraktor permesinan }\end{array}$ \\
\hline PT Zebra Nusantara Tbk & ZBRA & $\begin{array}{l}\text { kegiatan terutama di bidang angkutan taksi dan jasa angkutan } \\
\text { pada umumnya }\end{array}$ \\
\hline
\end{tabular}

